\title{
EFFECTIVENESS OF JASMINE OIL (JASMINUM OFFICINALE) MASSAGE ON REDUCTION OF LABOR PAIN AMONG PRIMIGRAVIDA MOTHERS
}

\author{
Hamid Mukhlis ${ }^{1}$, Nurhayati², Riska Wandini ${ }^{3}$ \\ 1Nursing Study Program, Aisyah University, Pringsewu Lampung-Indonesia.Email: hamid.mukhlis@stikesaisyah.ac.id \\ 2Diploma in Nursing Baitul Hikmah, Bandar Lampung-Indonesia. Email: nurhayati56488@gmail.com \\ ${ }^{3}$ Faculty of Medicine, Nursing and Health Sciences Malahayati University, Bandar Lampung, Indonesia. \\ Email: riskawandini@malahayati.ac.id
}

\begin{abstract}
Background: Intolerable labor pain encourages maternal use of painkillers such as analgesics and sedatives while these drugs have side effects on the mother and fetus.

Purpose: The proven that the effectiveness of jasmine oil (jasminum officinale) massage on reduction of labor pain among primigravida mothers

Methods: Quantitative research by using a quasi-experimental approach with one group pretest posttest. The population in this study was maternity during the phase I active with sample was 20 respondents. The study conducted on March 2018 at Teluk Pandan, Pesawaran, Lampung-Indonesia.

Results: The Effectiveness of counter pressure massage using jasmine oil (jasminum officinale) in reducing delivery pain with $p$-value 0,000

Discussion: The positively significant alteration in delivery pain score after therapy

Suggestions: That therapy could be alternative to help in reducing delivery pain.
\end{abstract}

Keywords: Jasmine Oil (Jasminum Officinale), Massage, Labor Pain, Primigravida Mothers

\section{INTRODUCTION}

Pain in contractions has been described as feeling similar to very strong menstrual cramps. The women often scream in this phase. However, howl and grunting may be encouraged to help reduce pain. that event may be experienced as an intense stretching and burning. Back labour is a term for specific pain occurring in the lower back, just above the tailbone, during childbirth. Regular Contractions in the maternal cause pain due to the stimulation of Sensory nerve endings of trigeminal nerve, and several complaints at the time such as the presence of pain in the abdomen, waist, back that spreads the backbone (Mochtar, \& Rustam, 2013; Sulistyawati, \& Nugraheny, 2010).

When complaints of pain have undiminished a long time with another complications, result that could cause death in the mother and baby, because pain made cause breathing and heart rate of the mother stimulated the bloodstream and oxygen of the placenta to be interfered. Pain, tension and fear would disturb of produce a number of catecholamines (stress hormone) is excessive as ephinephrin and norephinephrin. High levels of
Catecholamines in the blood can prolong labor by reducing the efficiency of uterine contractions and can harm the fetus by reducing blood flow to the placenta. This situation can result in management of labor becoming poor controlled and allowing trauma to the baby. (Wahyuningsih, 2014; Purnamasari \& Angraeni, 2019).

When intolerable of pain, mostly patients were using treatment a group of painkillers such as analgesics and sedatives while the drugs have side effects on the mother and fetus. For example, it can go through the placenta so have an effect on baby's breathing. Another side effects to the mother would be nausea and dizziness, and unable to control her abdominal muscles when occur uterine contractions, so labor becomes longer (Wahyuningsih, 2014; Haqiqi, 2016).

Base on data in Indonesia, the mother birth mortality rate (MBMR) was $228 / 100,000$ of mother. While the Infant Mortality Rate (IMR) shows a high number of 32 per 100,000 of infant (Indonesian Health Demographic and Survey, 2013; Nurrizka \& Saputra, 2013). The maternal deaths occur is very high number in developing countries. About $80 \%$ of 
EFFECTIVENESS OF JASMINE OIL (JASMINUM OFFICINALE) MASSAGE

ON REDUCTION OF LABOR PAIN AMONG PRIMIGRAVIDA MOTHERS

maternal deaths are a result of increased complications during pregnancy and childbirth (World Health Organization, 2014; Wulandari, \& Hiba, 2018). The Indonesian Demographic and Health survey (IDHS) shows that in Indonesia maternal mortality cases have increased quite significance. In 2012 that the Maternal Mortality Rate (MMR) in Indonesia reached 359 per 100,000 live births.

Cases of maternal and neonatal deaths in Lampung Province are still quite high. Base on data in 2014 there were 150 maternal deaths. The cases of maternal deaths by several reasons and one of those cases was due to trauma, compilcations and labor pain (Lampung Provincial Health Services Authority, 2015).

The presence of intolerable and continue labor pain, the midwifery care is very important, namely care that helps in feel safe and comfortable during labor, one of which is care to reduce pain (Mochtar, 2013).

There are many ways that can be used in relieving pain, the non-pharmacological therapy is alternative to prevent through blood stream without side effect. Non pharmacological therapy in pain management is a new trend that can be developed and is an alternative method that can be used to reduce pain. Non farmacology techniques that can improve the comfort of the mother during labor and reduce labor pain, one of which is therapy massage by using Jasmine oil.

The word 'aromatherapy' is derived from the
French word 'Aromatherapie', which was first created by French chemist Rene Maurice Gattefossé. He had experienced relieved from pain on his hand on due to a Bunsen burner after he put in his hand to $A$ pot of lavender. This was amazement the pain disappeared and he found the healing process was fast. He started to investigate and research the healing (Valnet, 2015; Nurgiwiati, 2015).

This study to confirm jasmine oil (jasminum officinale) in reducing delivery pain by providing a relaxing and comfortable effect that help increase in the release of endorphins that reduces pain by applying in coccyx area while massaging.

\section{RESEARCH METHODS}

The quantitative research, pseudo experiment which aims to confirm jasmine oil (jasminum officinale) in reducing delivery pain at the first active phase in primigravida.This research has been conducted for a month, on March 2018 at Teluk Pandan, Pesawaran Lampung, Indonesia. The Quasi Experiment design with the design of one group pretest-posttest. The population in this study was accidental sampling as a long as on March. The several steps on therapy such as touch or potent massage on the sacrum for 10 minutes performed 3 times in the interval 30 minutes by using jasmine/at siri oil. The Analysis of univariate data to notice in distribution frequency and bivariate analysis using a T-test.

Hamid Mukhlis' Nursing Study Program, Aisyah University, Pringsewu Lampung-lndonesia.

Email: hamid.mukhlis@stikesaisyah.ac.id

Nurhayati ${ }^{2}$ Diploma in Nursing Baitul Hikmah, Bandar Lampung-Indonesia. Email: nurhayati56488@gmail.com

Riska Wandini ${ }^{3}$ Faculty of Medicine, Nursing and Health Sciences Malahayati University, Bandar Lampung, Indonesia.

Email: riskawandini@malahayati.ac.id 
Malahayati International Journal of Nursing and Health Science, Volume 01, No.2, September 2018: 47-52

EFFECTIVENESS OF JASMINE OIL (JASMINUM OFFICINALE) MASSAGE

ON REDUCTION OF LABOR PAIN AMONG PRIMIGRAVIDA MOTHERS

\section{RESEARCH RESULTS}

Tabel 1. Average Distribution of Labor Pain

Pain During Childbirth (before therapy/pre-test)

Pain During Childbirth (after therapy/post-test)

\begin{tabular}{|c|c|c|c|c|c|c|c|c|c|c|c|c|c|}
\hline Mean & SE & Median & Min & Max & SD & Cl: $95 \%$ & Mean & SE & Median & Min & Max & SD & $\mathrm{Cl}: 95 \%$ \\
\hline 6,64 & 0,19 & 7,00 & 6,00 & 9,00 & 1,00 & $\begin{array}{l}6,25- \\
6,81\end{array}$ & 4,26 & 0,16 & 4,00 & 4,00 & 7,00 & 0,82 & $\begin{array}{l}3,75- \\
4,57\end{array}$ \\
\hline
\end{tabular}

Based on table 1, it found that before therapy jasmine oil (pre-test), the average pain score was of 6.64 with a standard deviation of 1.00 . The minimum score was of 6.00 and the maximum score of 9.00 that the average pain score was in between 6.25 to 6.81 . Whereas after therapy jasmine oil (post-test), the average pain score was 4.26 with a standard deviation of 0.82 The minimum score was 4.00 and the maximum score was 7.00 that the average pain score was in between 3.75 to 4.57 .

The normality test in distribution, the data was in a normal distribution. The skewness score was $<2$ then the data is normally distributed. The results are presented in table 2.

Tabel 2. Normality Tests in Distribution Data

\begin{tabular}{lllll}
\hline Variables & Skewness Score & $\begin{array}{l}\text { Standar } \\
\text { Error }\end{array}$ & Results & Conclusion \\
\hline Pain During Childbirth (pre test) & 0,443 & 0,426 & 1,03 & Normal \\
Pain During Childbirth (post test) & 0,422 & 0,425 & 1,02 & Normal \\
\hline
\end{tabular}

The hypothesis was continued to use the dependent t- test (paired sample t-test ) with a statistical in significant level of $p<0.05$, that confirm jasmine oil (jasminum officinale) in reducing delivery pain in primigravida

Tabel 3. The Effectiveness Jasmine Oil (Jasminum Officinale) In Reducing Delivery Pain

\begin{tabular}{lcccccc}
\hline Variable & Mean & SD & SE & p-Value & Cl 95\% \\
\hline Pain & DuringBefore & 6,53 & 1,00 & 0,18 & $\mathbf{0 , 0 0 0}$ & $(\mathbf{2 , 1 8 - 2 , 5 5 )}$ \\
\multicolumn{2}{l}{$\begin{array}{l}\text { Childbirth } \\
\text { N After }\end{array}$} & 4,16 & 0,83 & 0,15 & & \\
\hline
\end{tabular}

Hamid Mukhlis' Nursing Study Program, Aisyah University, Pringsewu Lampung-Indonesia.

Email: hamid.mukhlis@stikesaisyah.ac.id

Nurhayati ${ }^{2}$ Diploma in Nursing Baitul Hikmah, Bandar Lampung-Indonesia. Email: nurhayati56488@gmail.com

Riska Wandini ${ }^{3}$ Faculty of Medicine, Nursing and Health Sciences Malahayati University, Bandar Lampung, Indonesia.

Email: riskawandini@malahayati.ac.id 
EFFECTIVENESS OF JASMINE OIL (JASMINUM OFFICINALE) MASSAGE

ON REDUCTION OF LABOR PAIN AMONG PRIMIGRAVIDA MOTHERS

Based on table 3, that the results of the analysis by using paired sample t-test obtained the average of pain scores at pre test was of 6.53 with a standard deviation of 1.00 and the average pain score at post test was of 4.16 with a standard deviation of 0.83 . With $p$-value 0.000 it can be concluded that there is the effectiveness of jasmine oil (jasminum officinale) massage on reduction of labor pain among primigravida mothers, where the average pain score before therapy was significantly higher than the pain score after therapy.

\section{DISCUSSION}

Characteristics of the mothers based on age (2035 years old) was of $16(80 \%)$ mother, based on gestational age was of 39 weeks, the number mothers were more than 40 weeks gestational age of $6(39 \%)$. Based on BMI in excess categories was of $14(70 \%)$. unemployed was of $14(70.0 \%)$, and in a low education of $16(80 \%)$. Based on the mothers age, the experience of pain when rapidly declined of pain on mothers age on 20 years - 35 years old, there was a decrease in pain score 2.44 while those at the age of $<20$ years old and $>35$ years old was 2.00. This is because reproductive age has maturity physically and psychologically, due to the level of stress affects on pain response. Based on gestational age characteristics, the pain decreased rapidly on 41 weeks' gestation, which decreased score 2.5 from the previous pain score, based on BMI which rapidly decreased on mothers with excess BMI where pain response was a higher due to excessive suppression and after being given intervention decreased significant. Based on education level and employ that the faster subsided in the category of unemployed such as experiencing a decrease in pain score 2.55 and low education experienced a decrease in pain score 2.58 due to pain response being higher so that the pain subsided after being given an intervention.

The average pain response score before intervention jasmine oil (pre-test), the average pain score was 6.64 with a standard deviation of 1.00 . The minimum pain score response was of 6.00 and the maximum score of 9.00 . From the results of the interval estimation it can be concluded that $95 \%$ are believed that the average pain score was between 6.25 to 6.81 . The labor process is divided into four times, namely when I open the cervix or birth canal, where the cervix opens until there is an opening of 10 $\mathrm{cm}$, when II is called the time of discharge fetal, the third stage is called the release and expenditure of the placenta and IV stage is called observation (Wiknjosastro, 2005; Husna, 2010).

Childbirth is the process of fetal expulsion that occurs in term pregnancies (37-42 weeks), which can live outside the world, from the uterus through the birth canal or by other roads (Mochtar, 2011; Aisyah, \& Oktarina, 2012) Pain in labor in this case is the pain of uterine contractions which can lead to increased activity of the sympathetic nervous system, changes in blood pressure, heart rate, respiration and skin color and if not immediately addressed it will increase anxiety, fear and stress.

The results of this study was a same with previous that the results showed that there was a decrease in pain score after intervention of 3.27 In the opinion of the researchers the average pain score before intervention was in the category of severe pain. The level of pain in each respondent was also different - the opening of labor was also one of the different pain response of the level factors for each mothers, besides that the level of pain was also influenced by mothers experienced, the mothers in primiparo the pain score was higher due to the absence of childbirth experience so that the mother has not been able to overcome the pain, because one of the factors causing pain is personal experience. (Rejeki, Nurullita, \& Krestanti, 2013).

\section{The average pain score response after intervention (post-test)}

From the results of the study explained that after intervention (post-test), the average pain score was 4.16 with standard deviation of 0.83 . The minimum score was 3.00 and the maximum score was of 6.00 . From the results of the interval estimation, it can be concluded that $95 \%$ are believed that the average pain score response in between 3.85 to 4.47 .

Hamid Mukhlis' Nursing Study Program, Aisyah University, Pringsewu Lampung-Indonesia.

Email: hamid.mukhlis@stikesaisyah.ac.id

Nurhayati ${ }^{2}$ Diploma in Nursing Baitul Hikmah, Bandar Lampung-Indonesia. Email: nurhayati56488@gmail.com

Riska Wandini ${ }^{3}$ Faculty of Medicine, Nursing and Health Sciences Malahayati University, Bandar Lampung, Indonesia.

Email: riskawandini@malahayati.ac.id 
EFFECTIVENESS OF JASMINE OIL (JASMINUM OFFICINALE) MASSAGE

ON REDUCTION OF LABOR PAIN AMONG PRIMIGRAVIDA MOTHERS

Aromatherapy is one part of medicine alternative that uses volatile plant fluids known as essential oils and other aromatherapy compounds. Aromatherapy was developed by Muslim physicians and chemists since the discovery of distillation / distillation techniques for treatment was later developed in mainland Europe by a French chemist in 1937 (Koensoemardiyah, 2009; Zulkarnain, 2016). The techniques such as Counter pressure using jasmine oil was known to be effective in relieving back pain and labor pain (Maryunani, 2010).

The effectiveness of jasmine oil in primigravida, where the intensity of labor pain in primiparas is often more severe than labor pain in multi paras. This is because multiparas experience displacement (thinning of the cervix) together with cervical dilatation, whereas in primiparas the effacement process usually takes place earlier than cervical dilation. This process causes the intensity of contractions felt by primiparas to be heavier than multiparas, especially in the first labor stage (Maryunani, 2010; Sumarni, \& Yasin 2016). Pain expression response that can be observed from the client both behaviorally and physiologically. The intensity of pain is the severity of pain sensation. Pain tolerance is the intensity or duration of pain that the client will be able to endure to make further efforts to alleviate it (Maryunani, 2010). The labor pain will get stronger as the opening increases, the peak of pain will increase until the complete opening. The jasmine oil provides relaxation because the technique can close the pain message gate that will be delivered to the spinal cord and brain, besides that the pressure on this technique can activate endorphine compounds so that the pain sensation decreases. The effectiveness for term gestational age and with normal BMI because mothers with term pregnancies and index normal body mass are due to mothers with normal BMI that do not over-suppress the normal BMI.

\section{CONCLUSION}

There is the effectiveness of jasmine oil in maternal mothers primigravidianin, where the average score pain response was significantly a reduce after using jasmine oil.

\section{SUGGESTIONS}

Maternity Women is expected to be more cooperative when given measures to deal with pain by adding information during, it is hoped that these interventions will be carried out to assist the normal labor process. Future research to be apply another interventions such as relaxation of deep breathing or other techniques and material.

\section{REFERENCES}

Aisyah, S., \& Oktarina, A. (2012). Perbedaan Kejadian Ketuban Pecah Dini Antara Primipara Dan Multipara. Jurnal Midpro. Edisi I. Halaman, 1.

Haqiqi, B. R. (2016). Perbedaan Perubahan Tingkat Nyeri Persalinan Normal Antara Kelompok Dengan Dan Tanpa Aromaterapi Lavender Di Lamongan (Doctoral Dissertation, Universitas Airlangga).

Husna, U. (2010). Pengaruh Terapi Musik Instrumental Terhadap Perbedaan Intensitas Nyeri Persalinan Fase Aktif Kala 1 Pada Primigravidadi Wilayah Kerja Puskesmas Dangung-Dangung Tahun 2010. Penelitian, Fakultas Keperawatan.

Lampung Provincial Health Services Authority. (2015). Profil Kesehatan Kabupaten. Www.Depkes.Go.Id. Diakses Pada Tahun 2014

Maryunani, A. (2010). Nyeri Dalam Persalinan "Teknik Dan Cara Penanganannya". Jakarta: Trans Info Media.

Mochtar, R. (2013). Sinopsis Obsteri: Obstetri Fisiologi, Obstetri Patologi Ed. 3 Jilid 1. Jakarta: EGC.

Hamid Mukhlis' Nursing Study Program, Aisyah University, Pringsewu Lampung-lndonesia.

Email: hamid.mukhlis@stikesaisyah.ac.id

Nurhayati ${ }^{2}$ Diploma in Nursing Baitul Hikmah, Bandar Lampung-Indonesia. Email: nurhayati56488@gmail.com

Riska Wandini ${ }^{3}$ Faculty of Medicine, Nursing and Health Sciences Malahayati University, Bandar Lampung, Indonesia.

Email: riskawandini@malahayati.ac.id 
EFFECTIVENESS OF JASMINE OIL (JASMINUM OFFICINALE) MASSAGE

ON REDUCTION OF LABOR PAIN AMONG PRIMIGRAVIDA MOTHERS

Nadia, A. T. E. (2016). Pengaruh Massage CounterPressure Terhadap Adaptasi Nyeri Persalinan Kala 1 Dan Kecepatan Pembukaan Pada Ibu Bersalin. Jurnal IImiah Kesehatan, 8, 2.

Notoatmodjo. S (2014). Promosi Kesehatan Dan Perilaku Kesehatan. Jakarta: Rineka Cipta

Nurgiwiati, E. (2015). Terapi Alternatif Dan Komplementer Dalam Bidang Keperawatan. Bogor: Penerbit In Media.

Nurrizka, R. H., \& Saputra, W. (2013). Arah Dan Strategi Kebijakan Penurunan Angka Kematian Ibu (AKI), Angka Kematian Bayi (AKB) Dan Angka Kematian Balita (AKABA) Di Indonesia

Rejeki, S., Nurullita, U., \& Krestanti, R. (2013). Tingkat Nyeri Pinggang Kala I Persalinan Melalui Teknik Back-Effluerage Dan Counter-Pressure. Jurnal Keperawatan Maternitas, 1(2).

Septiawan, H. (2013). Faktor Yang Berhubungan Dengan Keluhan Nyeri Punggung Bawah Pada Pekerja Bangunan Di PT Mikroland Property Development Semarang Tahun 2012 (Doctoral Dissertation, Universitas Negeri Semarang).

Sidabutar, I. M., Kalesaran, A. F., \& Kepel, B. J. (2016). Hubungan Antara Pendidikan Dan Pengetahuan Dengan Tindakan Pemberantasan Sarang Nyamuk (PSN) DBD Masyarakat Di Desa Watutumou Kecamatan Kalawat Kabupaten Minahasa Utara. Ikmas, 8(3).
Sulistyawati, A., \& Nugraheny, E. (2010). Asuhan kebidanan pada ibu bersalin. Jakarta: Salemba Medika, 4.

Sumarni, S., \& Yasin, Z. (2016). Pengaruh Intervensi Akupresur Dalam Proses Distraksi Pasien Intranatal Untuk Menurunkan Nyeri Persalinan Di Wilayah Kerja Polindes Sriwahyuni Saronggi Sumenep. Wiraraja Medika, 6(1), 35-41.

Valnet, C. (2015). Essential oils \& Aromatherapy. Edizioni REI France

Wahyuningsih, M. (2014). Efektifitas aromaterapi lavender (lavandula angustifolia) dan massage effleurage terhadap tingkat nyeri persalinan kala I fase aktif pada primigravida Di BPS Utami Dan Ruang Ponek RSUD Karanganyar. Jurnal Penelitian Sekolah Tinggi IImu Keperawatan Kusuma Husada Surakarta.

Wiknjosastro (2005) Terhadap Perbedaan Intensitas Nyeri Persalinan Fase Aktif Kala 1 Pada Primigravida.

Wulandari, P., \& Hiba, P. D. N. (2018). Pengaruh Massage Effleurage Terhadap Pengurangan Tingkat Nyeripersalinan Kala I Fase Aktif Pada Primigravida Di Ruang Bougenville Rsud Tugurejo Semarang. Jurnal Keperawatan Maternitas, 3(1), 59-67.

Zulkarnain, Z. (2016). Penyalahgunaan Narkoba Dalam Perspektif Hukum Islam Dan Hukum Positif Indonesia (Doctoral Dissertation, Pascasarjana UIN Sumatera Utara).

Hamid Mukhlis' Nursing Study Program, Aisyah University, Pringsewu Lampung-Indonesia.

Email: hamid.mukhlis@stikesaisyah.ac.id

Nurhayati ${ }^{2}$ Diploma in Nursing Baitul Hikmah, Bandar Lampung-Indonesia. Email: nurhayati56488@gmail.com

Riska Wandini ${ }^{3}$ Faculty of Medicine, Nursing and Health Sciences Malahayati University, Bandar Lampung, Indonesia.

Email: riskawandini@malahayati.ac.id 